\title{
URGENSI KAJIAN NASIKH DAN MANSUKH DALAM BINGKAI GENERASI KEKINIAN (UPAYA MEMBUMIKAN TEORI KLASIK UNTUK MASA KINI)
}

\author{
Sefri Auliya \\ Dosen Agama Islam Poltekes Kemenkes Padang, auliyasef@gmail.com \\ Hidayatul 'Azizah Gazali \\ STAI PIQ Sumatera Barat, hidayatulaazizah@gmail.com
}

Diterima: 11 Mei 2018

Direvisi : 23 SSeptember 2018

Diterbitkan: 30 Desember 2018

\begin{abstract}
Ta'arudh (contradiction in understanding) between the ulama in understanding the syara texts' especially in the interpretation of the Koran became one of the principles of the birth of nasikh and mansukh theories. This article contains an analytical descriptive explanation of Nasakh, namely a statement that indicates the existence of an annulment of existing law, then nasikh, namely the argument that comes later that removes and replaces the existing law and mansukh, namely the previous law which has been deleted and replaced by the coming argument after that. Correct knowledge of the text that is nhurical and which can help one in understanding the context of the passage of a text of the Qur'an and can also know which part of the text of the Qur'an comes down first and which comes down later. Besides that, the knowledge of the Nasakh will also strengthen our belief that the source of the Qur'an which is essential is from Allah SWT. He is the one who removes a verse and replaces it with others according to His will. The problem of nasikh and mansukh is not something that stands alone, it is a part that is in the disciplines of interpretation and the science of ushul figh. Knowledge of nasikh and mansukh is very useful so that knowledge about the law is not chaotic and blurred. Therefore there are many atsar (sayings of friends) that encourage to know this problem. Especially for the present, knowledge of this theory is needed so as not to carelessly swallow and regurgitate the Qur'anic verses so that it is feared that it can tarnish its sanctity.
\end{abstract}

Keywords: Alquran, Nasikh, Mansukh, Masa Kini.

\begin{abstract}
Abstrak
Adanya gejala pertentangan (ta'arudh) di anatra para ulama dalam memahami nash-nash syara' khususnya pada penafsiran Alquran menjadi salah satu asas labirnya teori nasikh dan mansukh. Artikel ini memuat penjelasan deskriptif analitis tentang Nasakh yaitu pernyataan yang menunjukkan adanya pembatalan bukum yang telah ada, kemudian nasikh yaitu dalil yang datang kemudian yang menghapus dan menggantikan bukum yang telah ada sebelumnya dan mansukh yaitu bukum terdahulu yang telah dihapus dan digantikan oleh sebab dalil yang datang setelahnya. Pengetahuan yang benar tentang teks yang nasikh dan yang masukh dapat membantu seseorang dalam memahami konteks diturunkannya sebuah teks Alquran dan juga dapat mengetahui bagian mana dari teks. Alquran yang turun lebib dabulu dan yang turun kemudian. Disamping itu, pengetabuan tentang Nasakh ini juga akan memperteguh keyakinan kita bahwa sumber Alquran yang bakiki adalah dari Allah SWT. Dialah yang menghapus sesuatu ayat dan mengganti dengan yang lain sesuai kehendak-Nya. Masalah nasikh dan mansukh bukanlah sesuatu yang berdiri sendiri, ia merupakan bagian yang berada dalam disiplin ilmu tafsir dan ilmu ushul fiqh. Pengetahuan tentang nasikh dan mansukh sangat besar manfaatnya agar pengetabuan tentang bukum tidak kacau dan kabur. Oleh sebab itu terdapat banyak atsar (perkataan sababat) yang mendorong agar mengetahui masalah ini. Khususnya untuk masa kini,
\end{abstract}


pengetahuan tentang teori ini diperlukan agar tidak sembarangan dalam menelan dan memuntabkan kembali ayat-ayat Alquran sehingga dikhawatirkan dapat menodai kesuciannya.

Kata Kunci: Alquran, Nasikh, Mansukh, Masa Kini.

\section{PENDAHULUAN}

Alquran sejak pertama kali diturunkan kepada Nabi Muhammad SAW sampai sekarang ini mempunyai visi dan misi yang tetap, artinya bahwa prinsip dasar dan tujuan utama Alquran yang hendak disampaikan kepada umat ini tidak pernah berubah. Hanya saja pemahaman dan respon seseorang terhadap Alquran pada waktu itu berbeda dengan pemahaman seseorang yang datang pada kurun waktu lainnya.

Kitab Suci yang terdiri dari 30 juz, 114 kelompok surat dan 6000 ayat lebih ini mengandung berbagai jenis pembicaraan dan persoalan. Didalamnya terkandung antara lain nasihat, sejarah, dasar-dasar ilmu pengetahuan, keimanan, ajaran budi luhur, perintah dan larangan. Masalah-masalah yang disebutkan terakhir ini, tampak jelas dengan adanya ciri-ciri hukum didalamnya. Semua jenis masalah ini terkait satu dengan lainnya dan saling menjelaskan.

Terkait dengan itu, para ulama banyak mengulas prinsip tersebut. Mereka mencatat adanya pendapat yang memandang adanya tiap ayat atau kelompok ayat yang berdiri sendiri. Tapi semuanya berpendapat bahwa antara satu ayat dengan ayat lainnya dari alQur'an tidak ada kontradiksi (ta'arudl). Dari asas inilah lahir metode-metode penafsiran untuk meluruskan pengertian terhadap bagian-bagian yang sepintas lalu tampak saling bertentangan. Adanya gejala pertentangan (ta'arudl) yang demikian merupakan asas metode penafsiran dimana nasikh dan mansukh merupakan salah satu bagiannya.

Perdebatan atau perbedaan pendapat diantara ulama mengenai nasikh dan mansukh didalam Alquran sampai saat ini masih menjadi polemik yang berkepanjangan. Hal ini semuanya memiliki alasan atau argumentasi yang jelas, baik dari ulama pendukung Nasakh maupun yang menolaknya.

Artikel ini memuat penjelasan deskriptif analitis tentang Nasakh yaitu pernyataan yang menunjukkan adanya pembatalan hukum yang telah ada, kemudian nasikh yaitu dalil yang datang kemudian yang menghapus dan menggantikan hukum yang telah ada sebelumnya dan mansukh yaitu hukum terdahulu yang telah dihapus dan digantikan oleh sebab dalil yang datang setelahnya. Pengetahuan yang benar tentang teks yang nasikh dan yang masukh dapat membantu seseorang dalam memahami konteks diturunkannya sebuah teks Alquran dan juga dapat mengetahui bagian mana dari teks Alquran yang turun lebih dahulu dan yang turun kemudian. Disamping itu, pengetahuan tentang Nasakh ini juga akan memperteguh keyakinan kita bahwa sumber Alquran yang hakiki adalah dari Allah SWT. Dialah yang menghapus sesuatu ayat dan mengganti dengan yang lain sesuai kehendak-Nya.

\section{MAKNA NASAKH}

Kata Nasakh berasal dari bahasa arab yang diambil dari kata بنخ-ينسخ-نسخ Ditinjau dari segi bahasa, kata النسخ ini digunakan untuk menyatakan beberapa pengertian, yaitu:

Nasakh berarti الرفع والإزالة, yaitu menghilangkan atau menghapuskan. Misalnya ungkapan نسخت الثدس الظل artinya matahari menghilangkan bayang-bayang. Ini sesuai dengan firman Allah SWT dalam surat al-Hajj ayat 52:

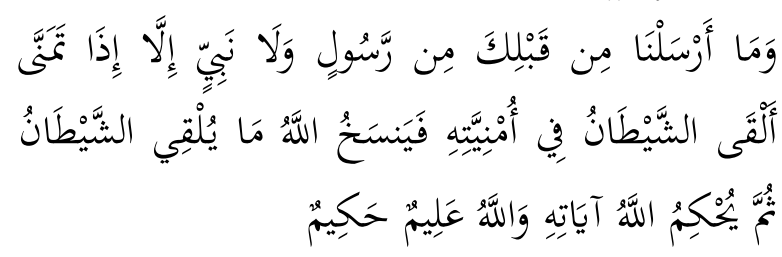

Dan Kami tidak mengutus sebelum kamu seorang rasulpun dan tidak (pula) seorang nabi, melainkan apabila ia mempunyai sesuatu keinginan, syaitanpun 
memasukkan godaan-godaan terbadap keinginan itu, Allah menghilangkan apa yang dimasukekan oleh syaitan itu, dan Allah menguatkan ayat-ayat-Nya. Dan Allab Maba Mengetabui lagi Maba Bijaksana. ${ }^{1}$

Nasakh berarti النقل, yaitu menukilkan atau memindahkan. Misalnya kalimat نسخت artinya saya memindabkan isi suatu kitab. Ini sesuai dengan firman Allah SWT dalam surat al-Jatsiyah ayat 29:

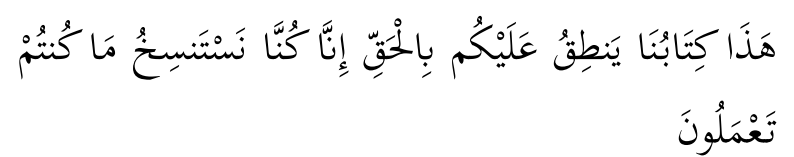

Inilah kitab (catatan) Kami yang menuturkan terbadapmu dengan benar. Sesunggubnya Kami telab menyurub mencatat apa yang telah kamu kerjakan. ${ }^{2}$

Nasakh berarti التبديل, yaitu mengganti atau mengubah. Misalnya ungkapan نسخ القاضى artinya bakim mengubah bukum dan menggantinya dengan bukum lain. ${ }^{3}$

Nasakh berarti التحويل, yaitu memalingkan atau mengalihkan. Misalnya kalimat تناسخ الموارث artinya perpindahan harta warisan dari seseorang kepada orang lain. ${ }^{4}$

Berdasarkan penjelasan diatas dimengerti bahwasannya Nasakh secara etimologi dapat disarikan kedalam empat kata kunci, yaitu menghilangkan, memindahkan, memalingkan dan menggantikan. Dalam kaidah bahasa nasikh dan mansukh berasal dari Nasakha yang terkumpul dalam dua isim. Nasikh berarti sesuatu yang menghilangkan, memindahkan, memalingkan dan menggantikan (berlaku sebagai isim fa'i), sedangkan mansukh berarti sesuatu yang

${ }^{1}$ Ibnu al-Jauzi, Nawasikh al-Qur'an, (Lebanon: Dar al-Kutub al-Ilmiah), h. 20

2 Armen Mukhtar, Nasakb Perkembangan Ilmu Tafsir Al-Qur'an, (Padang: IAIN IB Press, 1999), h. 35

3 Teungku Muhammad Hasbi ash-Shiddieqi, Ilmu-Ilmu al-Qur'an, (Semarang: PT. Pustaka Rizki Putra, 2002), h. 150

${ }^{4}$ Hasan Zaini dan Radhiatul Hasnah, Ulum al-Qur'an, (Batusangkar: STAIN Batusangkar Press, 2010), h. 126 dihilangkan, dipindahkan, dipalingkan dan digantikan (berlaku sebagai isim maf'uD).

\section{KONTROVERSI ULAMA TENTANG DEFINISI NASIKH DAN MANSUKH}

Dalam kajian bahasa para ulama tidak banyak berbeda pendapat terkait dengan nasikh dan mansukh. Akan tetapi, ketika memasuki ranah pemahaman secara istilah barulah muncul perbedaan pendapat diantara mereka, dimana penyebab itu semua tidak terlepas dari banyaknya pengertian Nasakh secara etimologis sebagaimana yang telah dijelaskan diatas. Dari beberapa definisi etimologis, masih sangat sulit ditentukan secara pasti arti mana yang paling sesuai dengan Alquran mengenai Nasakh ini. Pada akhirnya, tidak mengherankan jika dikalangan para ulama baik itu mutaqaddimin maupun mutaakhirin berbeda pendapat dalam mendefinisikannya dan itu semua tentunya tidak terlepas dari pemahaman mereka secara bahasa. Berikut penjelasan tentang pemahaman yang berbeda antara ulama mutaqaddimin dengan ulama mutaakbirin terkait dengan definisi Nasakh.

\section{Ulama Mutaqaddimin}

Menurut ulama mutaqaddimin arti nasikh dan mansukh dari segi terminologi mencakup kepada empat pengertian.

Pertama, Nasakh didefinisikan dengan "pembatalan bukum syara' oleh bukum syara". Definisi ini dirumuskan dalam redaksi yang beragam, diantaranya terdapat rumusan populer yang dibuat oleh Ibnu al-Hajib, yaitu membatalkan suatu hukum syara' dengan dalil syara' yang datang kemudian. ${ }^{5}$ Yang dimaksud dengan hukum syara' seperti yang terdapat dalam definisi Nasakh diatas adalah ucapan Allah SWT yang diwahyukan kepada Nabi Muhammad SAW yang berkaitan dengan perbuatan manusia baik dalam bentuk perintah maupun larangan. Dengan kata lain yang

${ }^{5}$ Muhammad Ali al-Shabuni, Rawa'I al-Bayan fi Tafsir Ayat al-Abkam min al-Qur'an, (Damaskus: Maktabah al-Ghazali, 1980), h. 89-90 
dimaksud dengan hukum syara' dalam definisi Nasakh tersebut adalah hukum agama Islam. Berangkat dari pengertian hukum syara' tersebut, maka Nasakh atau pembatalan hukum syara' oleh hukum syara' mengandung pengertian bahwa penghentian berkelakuan suatu hukum yang ditetapkan oleh Allah SWT melalui Nabi Muhammad SAW yang berkaitan dengan perbuatan manusia oleh hukum lain yang datang dari Allah SWT juga.

Pengertian hukum syara' sebagaimana telah diterangkan diatas memberikan pengertian bahwa permulaan wajibnya suatu ibadah dalam syari'at tidak mengandung Nasakh, seperti hukum tentang wajibnya sholat tidak mengandung pembatalan terhadap ketiadaan wajibnya sholat sebelum datangnya hukum yang mewajibkan itu. Kalaupun dikatakan bahwa dalam permulaan hukum itu terkandung pengertian pembatalan, maka pembatalan yang dimaksud adalah pembatalan oleh hukum syara' terhadap hukum akal yng menunjukkan ketiadaan kewajiban. Ini semua sesuai dengan firman Allah SW'T dalam surat al-Isra' ayat 15 :

$$
\text { وَمَا كُنَّا هُعَذِبِينَ حَتَّى نَبْعَثَ رَسُولاً }
$$

"Kami tidak akan meng'azab sebelum Kami mengutus seorang rasul."

Pengertian hukum syara' tersebut dapat dipahami bahwa suatu hukum yang telah ditetapkan secara syara' tidak dapat dibatalkan oleh argumen akal, tetapi hanya dapat dibatalkan oleh hukum secara syara' pula. Ini mengisyaratkan bahwa yang membatalkan sesungguhnya adalah Allah SWT. ${ }^{6}$

Kedua, Nasakh didefinisikan dengan pengkhususan suatu hukum syara' yang bersifat umum oleh hukum syara' yang bersifat khusus. ${ }^{7} \quad$ Dalam kajian ushul fiqh, definisi

6 Muhammad Abd al-Azhim al-Zarqani, Manah al-Irfan fi Ulum al-Qur'an, (Beirut: Dar al-Fikr, 1998), h. 176-177

${ }^{7}$ Abu Ishak Ibrahim bin Musa al-Syatibi, AlMuwafaqat fi Ushul al-Abkam, (Beirut: Dar al-Fikr, 1999), h. 65 tersebut disebut dengan "takhshish al-'am" yang berarti pengkhususan daripada yang umum. Perumusan definisi Nasakh tersebut didasarkan kepada pengertian bahwa didalam pengkhususan hukum terkandung adanya pembatalan oleh hukum yang mengkhususkan terhadap hukum yang dikhususkan, yakni membatalkan keberlakuan hukum terhadap yang tidak dikhususkan. ${ }^{8}$

Sebagai contoh dari definisi Nasakh yang kedua tersebut adalah hukum tentang kewajiban 'iddah bagi perempuan yang dicerai sebanyak tiga kali suci sebagaimana terdapat dalam surat al-Baqarah ayat 228:

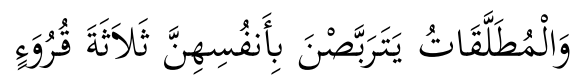

"Wanita-wanita yang ditalak hendaklah menahan diri (menunggu untuk menikah lagi) tiga kali suci."

Ketentuan ber-'iddah diatas bersifat umum yang karenanya berlaku bagi setiap perempuan yang dicerai. Kemudian kewajiban iddah tiga kali suci tersebut ditakhshish untuk wanita yang dicerai dalam keadaan belum dicampuri seperti yang disebutkan dalam surat al-Ahzab ayat 49:

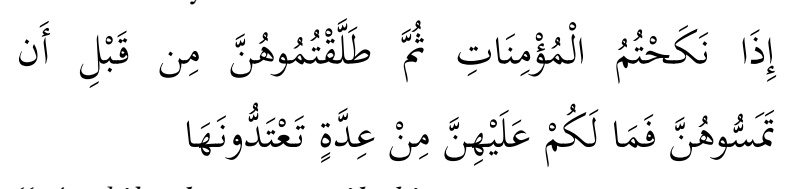

"Apabila kamu menikabi perempuan- perempuan yang beriman, kemudian kamu ceraikan mereka sebelum kamu mencampurinya maka sekali-sekali tidak wajib atas mereka 'iddah bagimu yang kamu minta menyempurnakannya."

Kemudian untuk wanita yang sedang hamil seperti yang terdapat dalam surat alThalaq ayat 4:

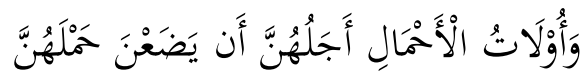

"Dan perempuan-perempuan yang hamil, waktu iddah mereka itu ialah sampai mereka melabirkan kandungannya."

Ketiga, Nasakh didefinisikan dengan "penetapan syarat terhadap suatu hukum

8 Armen Mukhtar, op.cit., h. 40-41 
terdahulu yang belum bersyarat". ' Definisi ini dikenal dengan istilah "taqyid al-muthlaq", yang secara bahasa berarti pengikatan atau pembatasan lafaz (hukum) yang lepas. Sebagaimana yang menjadi dasar dari definisi sebelumnya,perumusan definisi Nasakh yang ketiga ini juga didasarkan kepada pengertian bahwa dalam pembatasan lafaz (hukum) yang lepas, terkandung adanya pembatalan. Suatu hukum yang membatasi hukum lain yang bersifat lepas dinilai membatalkan sebagian yang terkandung dalam hukum yang lepas itu. ${ }^{10}$

Sebagai contoh dari definisi Nasakh yang ketiga ini adalah pembatasan hukum raqabah (budak) yang terdapat dalam surat al-Mujadilah ayat 3:

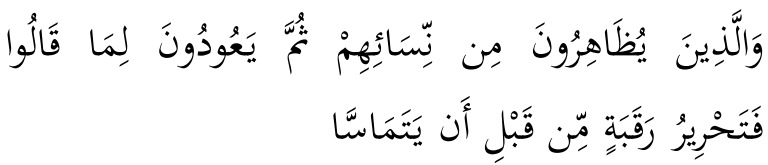

"Orang-orang yang menzhihar isteri mereka, kemudian mereka hendak menarik kembali apa yang mereka ucapkan, maka (wajib atasnya) memerdekakan seorang budak sebelum kedua suami isteri itu bercampur."

Lafaz raqabah yang berarti seorang budak dalam ayat tersebut bersifat muthlaq (lepas) karena tidak diberi taqyid (pembatasan) dengan sifat tertentu. Oleh karena itu, pengertian budak yang terkandung dalam ayat itu mencakup seluruh macam budak, baik budak yang mukmin maupun budak yang kafir. Kemudian ketentuan yang bersifat lepas itu dibatasi oleh sifat mu'minah, sebagaimana terdapat dalam surat al-Nisa ayat 92:

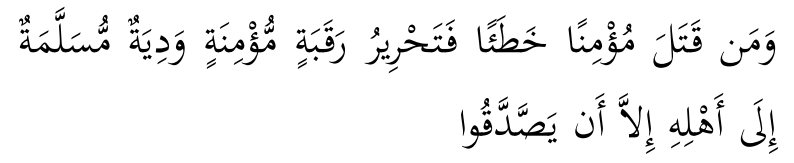

"Dan barangsiapa membunuh seorang mu'min karena tersalah (hendaklah) ia memerdekakan seorang hamba sahaya yang beriman serta membayar diyat yang diserabkan kepada keluarganya (si terbunub itu), kecuali jika mereka (keluarga terbunub) bersedekah."

\footnotetext{
9 Abu Ishak Ibrahim bin Musa al-Syatibi, op.cit., h. 65

10 Armen Mukhtar, op.cit., h. 41-42
}

Keempat, Nasakh didefinisikan dengan penjelasan yang datang kemudian terhadap suatu hukum yang bersifat samar. ${ }^{11}$ Definisi ini dikenal dengan istilah "tabyin al-mujmal", yang secara bahasa berarti penjelasan terhadap yang global. Seperti halnya dalam perumusan dua definisi sebelumnya, definisi Nasakh ini didasarkan kepada pengertian bahwa didalam penjelasan hukum yang samar itu terkandung adanya pembatalan hukum yakni membatalkan berlakunya hukum atas perbuatan atau pelaku yang sebelumnya masuk dalam kategori yang samar.

Sebagai contoh dari Nasakh berdasarkan definisi ini adalah pembatalan hukum menyemblih hewan bagi orang yang melaksanakan ibadah haji dengan cara tamattu' jika yang bersangkutan tidak mampu, kemudian diganti dengan hukum berpuasa sebanyak sepuluh hari. $^{12}$ Pembatalan dan penggantian hukum tersebut terdapat didalam surat al-Baqarah ayat 196:

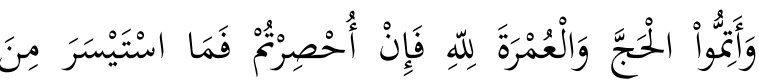

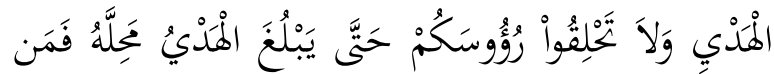

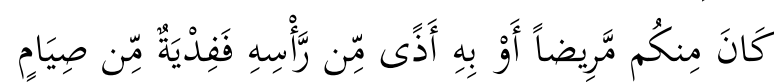

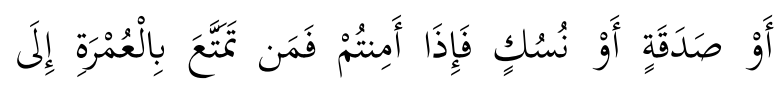

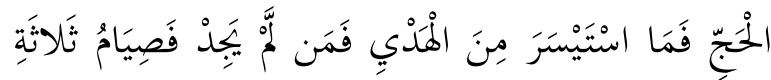

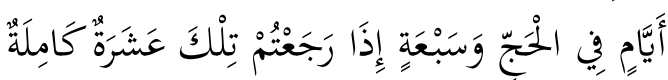
"Dan sempurnakanlah ibadah baji dan 'umrah karena Allah. Jika kamu terkepung (terbalang oleb musub atau karena sakit), maka (sembeliblab) korban yang mudab didapat, dan jangan kamu mencukur kepalamu sebelum korban sampai di tempat penyembelibannya. Jika ada di antaramu yang sakit atau ada gangguan di kepalanya (lalu ia bercukur), maka wajiblah atasnya berfid-yah, yaitu: berpuasa atau bersedekah atau berkorban. Apabila kamu telah (merasa) aman, maka bagi siapa yang ingin mengerjakan 'umrah sebelum baji (di dalam bulan haji), (wajiblah ia menyembelib) korban yang

${ }^{11}$ Abu Ishak Ibrahim bin Musa al-Syatibi, op.cit., h. 65

12 Armen Mukhtar, op.cit., h. 42-43 
mudah didapat. Tetapi jika ia tidak menemukan (binatang korban atau tidak mampu), maka wajib berpuasa tiga hari dalam masa haji dan tujuh hari (lagi) apabila kamu telah pulang kembali. Itulah sepulub (bari) yang sempurna."

Dengan demikian mereka memandang Nasakh sebagai dalil yang datang kemudian, dimana merupakan suatu pandangan yang lebih umum daripada arti menggugurkan atau merubah hukum pertama yang menjelaskan akhir masanya dan menjelaskan bahwa mengamalkan hukum itu tidak diharuskan selamanya oleh syara'. Maka mereka memperluas pengertian Nasakh yang terkumpul dalam empat pengertian, yaitu pembatalan, pengkhususan, pembatasan dan penjelasan.

\section{Ulama Mutaakbirin}

Menurut ulama mutaakbirin bahwa Nasakh sebagai dalil yang datang kemudian berfungsi untuk menggugurkan atau menghilangkan hukum yang pertama. Dengan demikian, mereka mempersempit ruang lingkupnya dengan beberapa syarat,baik yang nasikh maupun yang mansukh. Hal ini dilakukan untuk membedakannya dengan teori-teori yang dipakai oleh ulama terdahulu seperti pengkhususan, pembatasan dan penjelasan.

Manna' al-Qaththan mendefinisikan Nasakh dengan "mengangkat atau menghapus hukum syara' dengan dalil hukum syara'yang lain". Disebutkannya kata hukum disini, menunjukkan bahwa prinsip segala sesuatu hukum asalnya boleh (al-bara'ah al-asbliyab) tidak termasuk yang diNasakh. Kata-kata dengan dalil hukum mengecualikan pengangkatan atau penghapusan hukum yang disebabkan kematian atau gila, atau penghapusan dengan ijma'atau qiyas. Kata nasikh (yang menghapus) maksudnya adalah Allah (yang menghapus hukum itu), seperti firman-Nya dalam Alquran surat al-Baqarah ayat 106 :

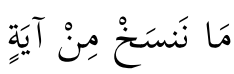

"Dan tidaklah Kami menghapus suatu ayat".

Kata itu juga digunakan untuk ayat atau sesuatu yang dengannya Nasakh dapat diketahui. Maka dikatakan ayat ini menghapus ayat itu dan digunakan pula untuk hukum yang menghapuskan hukum yang lain. ${ }^{13}$

Ibnu Katsir mendefinisikan Nasakh dengan "mengangkat atau menghapuskan hukum dengan dalil syara' yang datang kemudian". Maksudnya disini adalah meninggalkan hukum syara' yang datang pertama dan mengamalkan hukum syara' yang datang setelahnya dalam satu persoalan pokok. Sebagaimana dikatakan Farro' yaitu beramal dengan suatu ayat, kemudian turun ayat yang berikutnya, maka ia beramal dengan ayat yang itu dan meninggalkan ayat yang sebelumnya. ${ }^{14}$

Baidhawi mendefinisikan Nasakh dengan "penjelasan habisnya keberlakuan hukum syara' dengan cara menarik hukum syara' yang datang setelahnya". Maksudnya bahwa hukum yang mansukh itu disisi Allah SWT memiliki tujuan dan apabila telah sampai pada tujuan tersebut, maka habis pula batas mengamalkannya. Kemudian munculah kemestian bagi kita untuk mengamalkan syari'at yang datang kemudian. $^{15}$

Abdul Wahab Khalaf mendefinisikan Nasakh dengan 'membatalkan keputusan syara' dengan dalil syara' yang lainnya”. Maksudnya adalah bahwa pembatasan tersebut ada yang secara umum dan ada pula secara sebahagian. Dengan demikian, dalil yang datang kemudian membatalkan dalil yang telah berlaku sebelumnya. ${ }^{16}$

13 Syaikh Manna' Al-Qaththan, op.cit., h. 285-

14 Abdul Mat'al Muhammad al-Jabari, AlNaskh wa al-Masukh baina al-Itsbat wa al-nafyi, (Madinah: Maktabah Wahbah, 1987), h. 18

15 Sya'ban Muhammad Ismail, Nazriyatu alNaskh fi al-Syari al-Samawi, (Kairo: Darussalam, 1988), h. 11

16 Abdul Wahab Khalaf, Ilmu Ushul Figh, (Kairo: An-Nasyir, 1987), h. 17 
Dari beberapa definisi yang telah disebutkan diatas dapat dipahami, bahwa Nasakh adalah penghapusan hukum yang terdahulu oleh hukum yang datang kemudian. Dengan kata lain hukum yang datang belakangan telah menghapuskan hukum yang datang terdahulu, sehingga hukum yang datang kemudian mesti diamalkan. Jadi dalil yang menghapus hukum terdahulu disebut nasikh, sedangkan hukum yang dihapuskan oleh dalil terakhir disebut mansukh.

\section{URGENSI KAJIAN NASAKH DALAM TATARAN KEKINIAN}

Prinsip dasar dari kajian nasikh dan mansukh adalah melakukan perubahan ke arah yang lebih baik yang dilakukan langsung oleh Allah dalam kitabnya Alquran. Manusia dengan potensi akal dan fikiran yang telah dianugerahkan Allah juga melakukan berbagai tindakan perubahan, bahkan dalam masa modern ini sudah menjadi sesuatu yang lumrah karena memang dibutuhkan dan sudah menjadi tradisi. Contoh sederhana diantaranya; model rumah yang dahulu hanya menggunakan pintu kayu dan jendela kaca sebagai pengaman, sekarang dilengkapi dengan pagar tinggi dan terali besi serta alarm sensor dan CCTV; atau membersihkan rumah biasanya dahulu menggunakan sapu lidi atau sapu ijuk, sekarang sudah banyak yang menggantinya dengan vacum cleaner karena lebih praktis dan efisien; atau kompor masak rumah mayoritas dahulu menggunakan bahan bakar kayu atau minyak tanah, sekarang sudah beralih pada bahan bakar gas atau listrik karena lebih mudah didapatkan.

Terkait dengan adanya nasikh dan mansukh ini, maka tidak dapat dipisahkan dari sifat turunnya Alquran dan tujuan yang ingin dicapainya. Turunnya kitab suci Alquran memang tidak terjadi sekaligus, tapi berangsurangsur dalam kurun waktu lebih kurang 23 tahun. Awalnya persoalan ini banyak dipertanyakan oleh orang, namun akhirnya waktulah yang menjawab kalau semua itu bertujuan untuk pemantapan dan penyempurnaan syari'at. Dengan perantara berbagai situasi dan kondisi yang menaungi kelompok manusia, tempat, dan masanya, maka hukum pun bisa berkembang menjadi lebih universal dan komprehensif.

Masalah nasikh dan mansukh bukanlah sesuatu yang berdiri sendiri atau bagian dari ilmu tafsir saja, tapi juga termasuk dalam kajian penting ilmu ushul fiqh. Ini disebutkan dalam kaidah "Hukum itu mengikuti illat (sebab), jika illatnya ada maka hukum pun ada, tapi kalau illatnya tidak ada maka hukum pun tidak ada". Oleh karena itu, pengetahuan tentang nasikh dan mansukh sangat besar manfaatnya supaya pengetahuan tentang hukum tidak kacau dan kabur. Bahkan, sejak masa para sahabat pengetahuan tentang nasikh dan mansukh sudah diperintahkan secara tegas. Sebagaimana diriwayatkan oleh Abdul Wahab bin Mubarok al-Anmathi bahwasannya Ali bin Abi Thalib RA menceritakan suatu kisah kepada para sahabat (ketika bertanya kepada seorang hakim), maka Ali RA berkata "Apakah engkau mengetahui tentang nasikh dan mansukb"? Hakim menjawab "Tidak". Ali RA berkata "Engkau telah sesat dan menyesatkan". ${ }^{17}$

Seperti penjelasan sebelumnya bahwa para ulama menerangkan adanya perbedaan pendapat tentang kedudukan nasikh dan mansukh yang disebabkan oleh banyaknya penafsiran tentang kajian ini. Jika ditinjau dari segi formalnya fungsi pencabutan lebih nampak, tapi dari segi materinya fungsi penjelasan justru lebih menonjol. Meski demikian, pada akhirnya dapat dilihat adanya suatu fungsi pokok bahwa nasikh dan mansukh merupakan salah satu metode interpretasi hukum. Jadi, dalam penggalian ajaran dan hukum Islam yang terdapat dalam al-Quran ilmu ini sangat penting untuk mengetahui proses tasyri'

${ }^{17}$ Ibnu al-Jauzi, op.cit., h. 29 
(penetapan dan penerapan hukum), apakah sejalan dengan dinamika dan kebutuhan masyarakat yang selalu berubah, serta sejauh mana elastisitas dan perubahan hukum itu bisa diberlakukan.

Alquran sebagai kitab yang rabmatan lil 'alamin, memberikan manfaat tanpa dibatasi oleh dimensi zaman dan waktu. Kajian ini membuktikan bahwa ada hubungan yang spesial antara wahyu yang berasal dari Tuhan dengan realitas yang bersumber dari manusia. Apalagi, banyak sekali ditemukan bukti realitas kehidupan sekarang yang sangat berbeda dengan realitas kehidupan pada saat wahyu itu diturunkan. Adanya nasikh dan mansukh memberikan sebuah pelajaran bahwa Allah memberikan hukum secara bertahap, akibatnya hukum bisa berubah sesuai dengan kondisi masyarakat. Seperti pergantian hukum khamr atau minuman keras yang sampai empat kali tahapan. Masyarakat Arab yang terkenal berwatak keras memiliki tradisi meminum khamr yang sudah mengakar tentu tidak bisa dirubah sekaligus, sehingga dalam kasus ini Allah tidak serta-merta langsung mengharamkan khamr. Awalnya, di dalam Alquran hanya dijelaskan tentang buah-buahan yang bisa dibuatkan sesuatu yang memabukkan. Lalu, Allah menjelaskan bahwa khamr itu mudharatnya lebih besar daripada manfaatnya. Kemudian, Allah melarang mendekati shalat dalam keadaan mabuk. Terakhir, barulah Allah mengharamkan khamr secara keseluruhan karena merupakan bagian dari perbuatan setan.

Kisah ini menunjukkan kepada seluruh umat manusia khususnya umat Islam yang ada di zaman sekarang bahwa Allah melalui pesan Alquran sudah memberikan gambaran yang sangat jelas tentang konsep ajaran Islam. Suatu hukum yang terpakai pada suatu masa belum tentu bisa diterapkan di masa yang lain. Ketika kondisi berubah maka kebutuhan akan konsep hukum yang baru juga mutlak diperlukan. Ini juga menjadi indikasi bagaimana Allah mengajarkan kepada kita strategi dakwah yang pas untuk pemberlakuan sebuah hukum, sehingga tidak ada kesan dipaksakan dan kekhawatiran adanya pertentangan yang berlebihan.

Berdasarkan tahapan hukum khamr di atas, hukum haram yang diberlakukan di berbagai negara dan daerah yang ada di Timur Tengah, Indonesia, atau Malaysia yang mayoritas beragama Islam dengan kondisi dakwah dan pemahaman Islam yang sudah sempurna, tentu tidak akan masalah. Akan tetapi, untuk orang-orang yang berada di negara-negara Eropa dan Amerika tentu pendekatannya mesti berbeda. Bagi mereka minum khamr itu adalah suatu hal yang biasa, bahkan seperti minum air puth hangat yang katanya berguna untuk menghangatkan tubuh ketika cuaca dingin. Ditambah lagi kondisi mereka yang belum sempurna menerima dan memahami dakwah Islam, maka strateginya perlu menggunakan hukum-hukum lain terlebih dahulu sebelum diharamkan, karena kalau dipaksakan langsung dengan hukum haram, maka akan ada penolakan yang berujung tidak diterimanya dakwah Islam secara keseluruhan. Jadi, sekali lagi Allah melalui kajian nasikh dan mansukh ini sudah menunjukkan sebuah strategi dakwah Islam yang sangat luar biasa. Maksudnya, isi dan konten dari dakwah itu memang penting, tapi strategi dan pendekatan dakwah jauh lebih penting. Tidak mungkin ada pendakwah menyampaikan sesuatu yang salah dan sesat, namun pada akhirnya kesalahan dalam strategilah yang banyak membuat dakwah mereka tidak diterima.

Untuk zaman modern sekarang ini, semakin intens berinteraksi dengan Alquran, maka akan semakin banyak hikmah yang bisa diambil dari kajian nasikh dan mansukh. Apalagi dengan gaya hidup di zaman sekarang yang menuntut adanya banyak perubahan dan di saat yang bersamaan juga ada tekanan untuk berdaptasi dengan cepat. Ketika Tuhan dengan 
konsep nasikh dan mansukh bertujuan untuk merubah sesuatu supaya lebih sempurna, maka sesungguhnya manusia dengan fitrahnya juga memiliki tujuan yang sama ketika melakukan suatu perubahan.

Ketika Allah mengubah suatu hukum yang ada dalam Alquran yang merupakan sumber hukum utama dalam Islam, maka ada pelajaran yang bisa diambil sebagai berikut ${ }^{18}$ :

1. Menjaga kemashlahatan. Artinya, Allah tidak mungkin berbuat zalim kepada hamba-Nya dengan membiarkan berlakunya sesuatu yang batil tanpa mengubahnya dengan yang lebih baik.

2. Mengembangangkan pensyari'atan hukum sampai tingkat yang sempurna. Artinya, selalu disesuaikan dengan perkembangan dakwah Islam dan kondisi umat manusia.

3. Menguji kualitas keimanan. Artinya, dengan adanya hukum yang dirubah, maka bisa dilihat mana yang istiqamah mengikutinya atau justru jadi ingkar.

4. Menghendaki kebaikan dan kemudahan. Artinya, jika hukum itu beralih kepada yang lebih berat maka di dalamnya terdapat tambahan pahala, sedangkan jika beralih kepada hal yang lebih ringan maka di dalamnya terkandung kemudahan.

Hal ini juga berlaku pada manusia karena memang diberikan kemampuan untuk melakukan itu oleh Allah, seperti di Indonesia yang mengubah UUD 1945 sebagai sumber hukum utama negara dengan melakukan amandemen sampai empat kali. Sebagai warga negara yang baik, kita menerima dan mentaatinya karena tidak merasakan ada sesuatu yang sia-sia dan tidak bermanfaat dari perubahan tersebut.

Akhirnya, untuk menjawab berbagai pertanyaan yang muncul dikarenakan ragu dengan eksistensi dan hikmah dari kajian nasikh dan mansukh, maka perlu dikorelasikan dengan situasi umat di zaman modern, sehingga bisa terjawab dengan data dan fakta.
Walaupun ilmu ini prakteknya sudah ada sejak 14 abad yang silam, tapi pola dan aplikasinya masih banyak ditemukan sampai saat ini.

\section{HIKMAH NASIKH DAN MANSUKH UNTUK GENERASI SEKARANG DALAM BERAGAMA}

Masalah nasikh dan mansukh bukanlah sesuatu yang berdiri sendiri, ia merupakan bagian yang berada dalam disiplin ilmu tafsir dan ilmu ushul fiqh. Pengetahuan tentang nasikh dan mansukh sangat besar manfaatnya agar pengetahuan tentang hukum tidak kacau dan kabur. Oleh sebab itu terdapat banyak atsar (perkataan sahabat) yang mendorong agar mengetahui masalah ini. Sebagaimana diriwayatkan oleh Abdul Wahab bin Mubarok al-Anmathi bahwasannya Ali bin Abi Thalib RAmenceritakan suatu kisah kepada para sahabat (ketika bertanya kepada seorang hakim), maka Ali RA berkata "apakah kau mengetahui tentang nasikh dan mansukh"? Hakim menjawab "tidak". Ali RA berkata "kan telah sesat dan menyesatkan". 19

Seperti penjelasan-penjelasan yang sebelumnya bahwa para ulama menerangkan tentang adanya perbedaan pendapat tentang kedudukan Nasakh, ini terkait dengan banyaknya penafsiran dari Nasakh itu sendiri. Jika ditinjau dari segi formalnya, maka fungsi pencabutan lebih nampak. Tapi bila ditinjau dari segi materinya, maka fungsi penjelasan leb ih menonjol. Meski demikian, pada akhirnya dapat dilihat adanya suatu fungsi pokok bahwa Nasakh merupakan salah satu metode interpretasi hukum.

Ilmu nasikh dan mansukh dalam penggalian ajaran dan hukum islam dalam Alquran sangat penting untuk mengetahui proses tasyri' (penetapan dan penerapan hukum) islam sejalan dengan dinamika kebutuhan masyarakatnya yang selalu berubah, sejauh mana elastisitas ajaran dan hukumnya serta sejauh mana perubahan hukum itu 
berlaku. Disamping itu, untuk menelusuri 'illat (alasan ditetapkannya suatu hukum), sehingga pemberlakukan hukum tersebut bisa secara longgar dan ketat sesuai dengan kondisi yang mengitarinya. Di antara hikmah dari kajian ini, adalah dapat menjaga kemashlahatan hamba, dimana Allah SWT tidak mungkin berbuat zhalim kepada hamba-Nya dengan membiarkan berlakunya sesuatu yang bathil tanpa mengubahnya dengan yang lebih baik.

Selain itu, dapat mengembangangkan pensyari'atan hukum sampai tingkat yang sempurna, sesuai dengan perkembangan dakwah agama dan perkembangan kondisi umat manusia. Juga dapat dijadikan standar untuk menguji kualitas keimanan seorang mukallaf, dengan cara adanya hukum yang dihapus dan diganti, kemudian apakah dia mengikutinya atau tidak.

Adanya kajian keIslaman khususnya yang bersifat prinsipil seperti Nasakh, adalah untuk mencari kebaikan dan kemudahan bagi umat, sebab jika hukum itu beralih kepada hal yang lebih berat maka didalamnya terdapat tambahan pahala, sedangkan jika beralih kepada hal yang lebih ringan maka didalamnya terkandung kemudahan.

Diharapkan, pemahaman yang benar tentang kajian nasikh dan mansukh akan memberikan banyak keuntungan bagi umat Islam. Dalam konteks dakwah, kajian ini bisa dijadikan sebagai strategi bahwa pendekatan terhadap objek dakwah itu tidak mungkin sama karena bisa jadi pemahamannya tentang ajaran Islam juga berbeda-berbeda, maka pemberlakuan hukum Islam pada satu masyarakat belum tentu bisa diterapkan pada masyarakat yang lain. Kesalahan dalam menerapkan strategi dalam berdakwah akan membuat konten dakwah yang begitu sempurna akan sia-sia karena tidak diterima ditengah masyarakat. Kemudian, kajian ini juga menjadi bukti bahwa Islam memang merupakan agama yang rahmatan lil alamin. Islam dengan berbagai hukumnya tidak pernah mengandung SARA dan diskriminasi, sehingga bukan hanya bisa dinikmati oleh sekelompok orang pada masa tertentu saja, tapi tetap bisa diaplikasikan lintas generasi tanpa dibatasi oleh dimensi zaman dan waktu.

\section{KESIMPULAN}

Nasikh dan mansukh secara bahasa berasal dari kata نسخ yang berarti menghilangkan, memindahkan, mengganti atau memalingkan. Nasikh berarti yang menghapuskan (isim fai'il) dan mansukh bearti yang dihapuskan (isim maf'ul). Sedangkan secara istilah terjadi perbedaan pendapat, menurut ulama mutaqaddimin lebih cenderung memaknai nasikh dengan dalil syar'i yang ditetapkan kemudian, tetapi ulama mutaakbirin lebih cenderung memaknai nasikh dengan hukum yang ditetapkan terakhir.

Berkenaan dengan keberadaan Nasakh didalam Alquran terjadi perbedaan pendapat diantara para ulama. Kelompok yang pro dengan Nasakh memiliki dalil naqliah dan argumentasi 'aqliah, diantaranya adalah Imam Syafi'i, Ibnu Katsir dan al-Maraghi. Sementara kelompok yang kontra dengan adanya Nasakh juga mempunyai dalil naqliah dan argumentasi 'aqliah, diantaranya adalah Abu Muslim alAshfahani, Imam ar-Razi dan Muhammad Abduh. Perbedaan ini mayoritas bermula dari pemahaman mereka tentang kata-kata "ayat" yang terdapat dalam surat al-Baqarah ayat 106 dan surat an-Nahl ayat 101, dimana kelompok yang mendukung mengartikannya ayat Alquran, sedangkan kelompok yang menolak mengartikannya dengan mukjizat dan syari'at.

Bentuk-bentuk Nasakh dapat dilihat dari tiga sisi; Cakupan ruang lingkupnya, yaitu Nasakh sharih, Nasakh dhimmy, Nasakh kully dan Nasakh jur'iy; Bacaan dan hukumnya, yaitu Nasakh hukum dan bacaannya sekaligus, Nasakh hukumnya saja tapi bacaannya tidak dan Nasakh bacaannya saja tapi hukumnya tidak; Otoritasnya, yaitu Nasakh Alquran dengan Alquran, Nasakh Alquran dengan 
hadist, Nasakh hadist dengan Alquran, dan Nasakh hadist dengan hadist.

Pengetahuan tentang Nasakh sangat penting karena dengan begitu kita akan mengetahui proses penetapan dan tujuan dari suatu hukum. Sehingga pada akhirnya kita akan bisa memahami hukum secara sempurna dan benar yang tentunya juga akan selalu sejalan dengan dinamika kehidupan masayarakat yang selalu berubah. 


\section{DAFTAR KEPUSTAKAAN}

Ibnu Katsir, Ismail, Tafsir al-Qur'an al-'Az̧im, Singapura: Sulaiman Mar'iy, 2002.

Ismail, Sya’ban Muhammad, Nazriyatu al-Naskh fi al-Syar'i al-Samawi, Kairo: Darussalam, 1988.

Al-Jabari, Abdul Mat'al Muhammad, Al-Naskh wa al-Mansukh baina al-Itsbat wa al-nafyi, Madinah: Maktabah Wahbah, 1987.

Al-Jauzi, Ibnu, Nawasikh Alquran, Lebanon: Dar al-Kutub al-Ilmiah.

Khalaf, Abdul Wahab, Ilmu Ushul Figh, Kairo: An-Nasyir, 1987.

Al-Maraghi, Ahmad Mustafa, Tafsir al-Maraghi, Mesir: Al-Halabiy, 1946.

Mukhtar, Armen, Nasakh Perkembangan Ilmu Tafsir Alquran, Padang: IAIN IB Press, 1999.

Al-Qaththan, Syaikh Manna', Pengantar Studi Ilmu Alquran, Jakarta: Pustaka Al-Kautsar, 2006.

Said, M, Terjemahan Alquran al-Karim, Bandung: PT. Al-Ma’arif, 1987.

Al-Shabuni, Muhammad Ali, Rawa'i al-Bayan fi Tafsir Ayat al-Abkam min Alquran, Damaskus: Maktabah al-Ghazali, 1980.

Ash-Shiddieqi, Teungku Muhammad Hasbi, Ilmu-Ilmu Alquran, Semarang: PT. Pustaka Rizki Putra, 2002.

Al-Syatibi, Abu Ishak Ibrahim bin Musa, Al-Muwafaqat fi Ushul al-Abkam, Beirut: Dar alFikr,1999.

Yusuf, Kadar M., Studi Alquran, Jakarta: Amzah, 2010.

Zaini, Hasan dan Radhiatul Hasnah, Ulum Alquran, Batusangkar: STAIN Batusangkar Press, 2010.

Al-Zarqani, Muhammad Abd al-Azhim, Manah al-Irfan fi Ulum Alquran, Beirut: Dar al-Fikr, 1998. 